\title{
SUBSTITUSI TEPUNG IKAN TERI (Stolephorus sp.) DALAM PEMBUATAN KUE SEMPRONG SEBAGAI SUMBER KALSIUM UNTUK ANAK SEKOLAH
}

\author{
Adlina Dhiyaul Haq, Nani Ratnaningsih, Badraningsih Lastariwati \\ Program Pendidikan Kesejahteraan Keluarga Pascasarjana \\ Fakultas Teknik Universitas Negeri Yogyakarta \\ Jalan Colombo No.1, Karang Malang, Caturtunggal, Depok, Sleman, Yogyakarta 55281 \\ Diterima: 23 Juni 2021/Disetujui: 10 Oktober 2021 \\ "Korespondensi: adlina.dhiyaulhaq@gmail.com
}

\begin{abstract}
Cara sitasi: Haq AD, Ratnaningsih N, Lastariwati B. 2021. Substitusi tepung ikan teri (Stolephorus sp.) dalam pembuatan kue semprong sebagai sumber kalsium untuk anak sekolah. Jurnal Pengolahan Hasil Perikanan Indonesia. 24(3): 292-300.
\end{abstract}

\begin{abstract}
Abstrak
Salah satu bahan pangan sumber kalsium yang dibutuhkan oleh anak-anak adalah ikan teri, namun pemanfaatannya dalam produk makanan tradisional masih terbatas. Kue semprong mempunyai potensi sebagai makanan tradisional yang bersifat fungsional. Penelitian ini bertujuan untuk mengetahui formulasi kue semprong dengan substitusi tepung ikan teri medan, tingkat kesukaan dan kandungan gizinya dengan uji proksimat dan kalsium. Penelitian dilakukan dalam empat tahap yaitu define untuk menemukan resep acuan kue semprong, design untuk mengembangkan resep acuan terpilih dengan substitusi tepung teri medan sebanyak 5\%, 10\%, dan $15 \%$ development untuk uji validitas kepada ahli pangan dan gizi serta merancang kemasan kue semprong teri medan, serta terakhir disseminate untuk menguji kesukaan produk oleh 100 panelis dari anak sekolah. Substitusi tepung ikan teri medan pada kue semprong yang terbaik yaitu $15 \%$. Uji kesukaan terhadap produk acuan yaitu 4,0 (disukai) dan produk pengembangan yaitu 4,9 (sangat disukai). Kandungan gizi kue semprong teri medan terdiri dari protein 10,77 g, lemak 26,49 g, karbohidrat $57,04 \mathrm{~g}$, dan energi 486,65 kkal/100 g produk. Kue semprong teri medan dapat dikategorikan sebagai camilan sumber kalsium karena mengandung kalsium $820,63 \mathrm{mg} / 100 \mathrm{~g}$. Oleh karena itu, kue semprong teri medan dapat direkomendasikan sebagai camilan untuk anak sekolah.
\end{abstract}

Kata kunci: kandungan gizi, litbang, tepung teri, semprong

\begin{abstract}
One of the food sources of calcium needed by children is anchovy, but its use in traditional food products is still limited. Semprong cake has the potential as a traditional food that is functional. This study was aimed to determine the formulation of semprong cake with anchovy flour substitution, level of preference and nutritional content with proximate and calcium tests. The research was consist of 4 stages, namely define to find a reference recipe for semprong cake. Design stage by developing selected reference recipes with the substitution of field anchovy flour as much as 5\%,10\%, and 15\%. In the Development phase, validity tests were carried out on food and nutrition expert lecturers and designing the semprong anchovy cake packaging. Disseminate stage to test product preferences by 100 panelists from school children. The best substitution of anchovy flour on semprong cake is $15 \%$. The preference test for the reference product is 4.0 (preferred) and the development product is 4.9 (strongly preferred). The nutritional content of the Medan anchovy semprong cake consists of $10.77 \mathrm{~g}$ protein, $26.49 \mathrm{~g}$ fat, $57.04 \mathrm{~g}$ carbohydrates, and 486.65 $\mathrm{kcal} / 100 \mathrm{~g}$ of product energy. Medan anchovy semprong cake can be categorized as a calcium source snack because it contains $820.63 \mathrm{mg} / 100 \mathrm{~g}$ of calcium. Therefore, the Medan anchovy semprong cake can be recommended as a snack for school children.
\end{abstract}

Keywords: anchovy flour, nutritional content, research and development, semprong cake 


\section{PENDAHULUAN}

Permintaan ikan sebagai sumber pangan setiap tahun semakin meningkat, terutama ketika pemerintah berencana untuk membuat masyarakat menyukai ikan. Dibandingkan dengan potensi sumber daya perikanan, tingkat konsumsi ikan di Indonesia relatif rendah. Konsumsi ikan pada tahun 2018 sebesar 50,69 kg, dan pada tahun 2019 meningkat menjadi $54,50 \mathrm{~kg}$ setiap tahun. Tujuan KKP adalah meningkatkan konsumsi ikan nasional sebesar $56,39 \mathrm{~kg}$ pada tahun 2020 dan menjadi $62,50 \mathrm{~kg}$ pada tahun 2024 (KKP 2019).

Ikan teri nasi populer bagi masyarakat Indonesia dan merupakan komoditas hasil perikanan potensial. Ikan teri nasi mudah didapatkan, bernilai ekonomis tinggi, dan dapat diproduksi baik dalam kondisi kering maupun segar. Selain itu, ikan teri kaya akan protein, lemak, serta vitamin dan mineral yang penting untuk proses tumbuh kembang dan kecerdasan manusia. Oleh karena itu, potensi ikan teri nasi bernilai tinggi dalam sektor industri di Indonesia (Setiyawati 2020).

Ikan teri nasi terdapat di Indonesia, dengan ciri-ciri berukuran kecil, bentuk silindris, kepala pendek, warna dominan putih, dengan aroma khas. Kelebihan lain dari ikan teri adalah seluruh tubuh (termasuk tulangnya) dapat dimakan, sehingga merupakan sumber kalsium untuk anak-anak.

Masa anak-anak dan remaja sangat membutuhkan asupan energi dan protein serta kalsium yang cukup untuk perkembangan puncak masa tulang. Kalsium berperan sangat penting dalam metabolisme tubuh, penghubung antar saraf dan bekerja pada pergerakan jantung dan otot. Massa tulang yang optimal ada di masa pubertas pada anak perempuan (11-14 tahun) dan anak laki-laki (usia 14-16 tahun), dengan 51\% massa tulang puncak terakumulasi saat pertumbuhan pubertas hingga mencapai $37 \%$ dari kepadatan mineral tulang usia dewasa. Setiap $100 \mathrm{~g}$ ikan teri kering terkandung $1.200 \mathrm{mg}$ kalsium (Sudewi 2018).

Ikan teri nasi tergolong makanan yang mudah rusak atau disebut perishable food. Untuk mencegah hal tersebut, diperlukan pengolahan ikan teri nasi untuk memperpanjang umur simpannya. Bahan pangan ikan dapat diolah menjadi produk jadi (misalnya ikan kering dan kaleng) atau setengah jadi (misalnya tepung ikan). Tepung ikan memiliki daya simpan lebih lama serta dapat diolah menjadi berbagai jenis pangan misalnya kue semprong. Tepung ikan teri nasi yang digunakan sebagai pengganti tepung beras dalam pembuatan kue semprong adalah pilihan yang menjanjikan, terutama dari segi kualitas nutrisi yang dihasilkan.

Beberapa studi sebelumnya tentang pemanfaatan tepung ikan teri nasi telah yaitu kajian penerapan GMP dan SSOP ikan teri nasi setengah kering di Kabupaten Tuban (Amin et al. 2018); kadar protein dan kalsium pada crackers yang diganti bahan tepung kedelainya dengan tepung teri (Sulistyowati et al. 2015); corn flakes yang ditambahkan tepung ikan teri nasi (Rahmi etal.2018); pai miniyang ditambahkan tepung ikan teri dan tepung kacang merah (Faroj 2019); kukis bagea yang diganti tepung sagunya dengan tepung ikan teri (Rahman dan Nalu 2021). Namun pemanfaatan tepung ikan teri nasi pada kue tradisional, misalnya kue semprong belum pernah dipublikasikan.

Kue semprong adalah kue tradisional Indonesia yang menggunakan tepung beras, dibuat dengan cara pemanggangan pada cetakan khusus kue semprong kemudian digulung menyerupai lampu semprong menggunakan sumpit. Semprong mudah didapat di pasar tradisional ataupun dijajakan secara kaki lima di berbagai daerah (Prisila et al. 2020). Kue semprong digemari karena rasanya yang manis, aroma santan yang khas serta testurnya yang renyah. Tujuan penelitian ini adalah menentukan konsentrasi terbaik dari tepung ikan teri dalam pembuatan kue semprong, mengetahui tingkat kesukaan, dan kandungan gizinya. Hasil penelitian ini diharapkan memiliki kontribusi dalam menghasilkan produk camilan sebagai sumber kalsium untuk anak-anak.

\section{BAHAN DAN METODE Bahan dan Alat}

Bahan baku yang digunakan pada penelitian ini yaitu ikan teri nasi yang berasal dari Medan, Sumatra Utara. Jumlah ikan teri 
nasi yang digunakan sebesar $1.000 \mathrm{~g}$, diolah menjadi tepung di laboratorium kimia PTTB Fakultas Teknik Universitas Negeri Yogyakarta. Bahan baku lainnya yaitu tepung beras, tepung sagu, telur, margarin, gula, biji wijen, dan santan. Bahan-bahan yang digunakan untuk analisis proksimat yaitu akuades, $\mathrm{NHO}_{3}$ (Merck), dan $\mathrm{HCLO}_{4}$ (Merck). Alat yang digunakan dalam pembuatan kue semprong yaitu baskom, wadah aluminium, sendok, spatula, ballon whisk, cetakan kue semprong, kuas, sumpit, gelas ukur, kompor dan timbangan. Selain itu alat-alat laboratorium yang digunakan yaitu ayakan 60 mesh, cabinet dryer, blender, sendok, baskom, timbangan.

\section{Metode}

Penelitian ini dimulai dengan pembuatan tepung ikan teri nasi, pembuatan formulasi optimal pada kue semprong dengan campuran tepung ikan teri nasi, analisis organoleptik dengan parameter warna, rasa, aroma, tekstur dan sifat keseluruhan. Penelitian ini juga menganalisis zat gizi yaitu uji proksimat yang terdiri dari kadar air, kadar abu, protein, lemak, dan karbohidrat. Pengujian zat gizi lain juga dilakukan pada kandungan kalsium.

Penelitian ini menggunakan desain penelitian dan pengembangan (research and development) dengan model 4D yang terdiri dari define (analisis kebutuhan), design (perencanaan), development (pengembangan), disseminate (penyebarluasan). Pada tahap define, peneliti merumuskan produk kue semprong dengan menggunakan formula dasar kue semprong dengan memperhatikan beberapa aspek seperti rasa, aroma, warna dan tekstur dalam pembuatan kue semprong tersebut. Pada tahap design, dilakukan modifikasi pada formula kue semprong tersebut dengan membuat campuran perbandingan 5\%,10\% dan 15\% tepung ikan teri nasi. Tahap selanjutnya yaitu development dengan melakukan uji validitas produk pengembangan kue semprong tersebut oleh dosen ahli gizi dan pangan serta merancang kemasan kue semprong teri medan. Tahap terakhir yaitu disseminate dengan melakukan uji mutu organoleptik yang dilakukan oleh 100 panelis tidak terlatih dengan memberikan score sheet meliputi warna, aroma, rasa, tekstur dan keseluruhan serta analisis proksimat (kadar air, kadar abu, protein, lemak, energi dan kalsium).

\section{Pembuatan tepung ikan teri (Ramadhan et al. 2019)}

Proses pembuatan tepung ikan teri nasi dimulai dari mencuci ikan teri terlebih dahulu menggunakan air mengalir untuk menghilangkan kotoran pada ikan teri. Tahap selanjutnya yaitu ikan teri nasi direndam di air panas selama kurang lebih 8 jam lalu diberi perasan jeruk nipis dan irisan jahe agar menghilangkan aroma amis pada ikan teri nasi. Selanjutnya tahap penirisan ikan teri nasi kemudian proses pengeringan menggunakan cabinet dryer selama 24 jam disuhu $40{ }^{\circ} \mathrm{C}$. Selanjutnya ikan teri nasi dihaluskan menggunakan penggiling tepung kemudian diayak dengan tingkat kehalusan 60 mesh. Proses pengolahan tepung teri medan dapat dilihat pada Figure 1.

\section{Pembuatan kue semprong (Wati 2013)}

Proses pembuatan kue semprong teri medan dimulai dengan mencampurkan telur, gula halus, tepung beras, tepung sagu, dan tepung ikan teri nasi diaduk sampai tercampur menggunakan balloon whisk. Selanjutnya penambahan santan, margarin, dan biji wijen. Semua bahan tercampur rata tuangkan 20 g adonan pada cetakan kue semprong dan dijepit, masak di atas api kecil sambil dibolakbalik. Kemudian gulung kue semprong yang sudah kecokelatan menggunakan sumpit agar bentuknya menyerupai tabung. Proses pembuatan kue semprong dapat dilihat pada Figure 2.
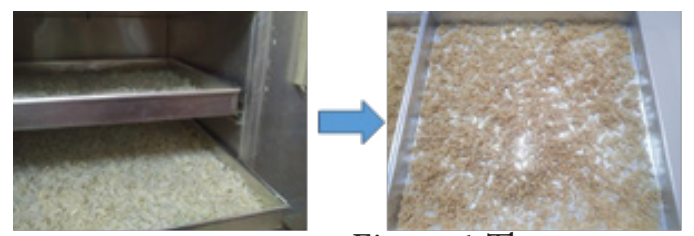

Figure 1 The process of making field anchovy flour 


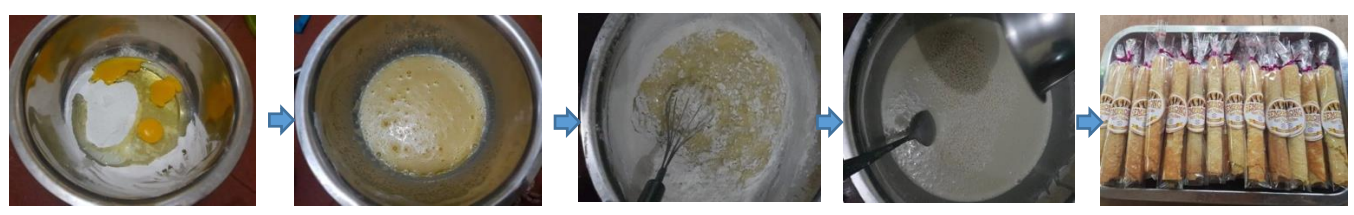

Figure 2 The process of making anchovy semprong cake

\section{Analisis Data}

Analisis data yang digunakan dalam penelitian ini adalah deskriptif. Tingkat kesukaan panelis tentang kualitas kue semprong teri medan didapatkan melalui penilaian secara uji organoleptik dengan menilai enam indikator yaitu, warna, aroma, rasa, tekstur, kemasan dan keseluruhan (overall) melalui score sheet, jawaban panelis untuk score sheet pada penilaian uji organoleptik menggunakan jawaban (sangat suka, suka, agak suka, dan tidak suka) yang dinyatakan menggunakan kategori jawaban.

Hasil pengukuran dari panelis score sheet pada uji organoleptik akan dianalisis menggunakan Microsoft Excel, kemudian data kandungan gizi yang diperoleh dianalisis dengan menggunakan uji paired $t$-tes dengan taraf signifikansi 5\%.

\section{HASIL DAN PEMBAHASAN Define}

Tahap define adalah menetapkan atau menentukan produk serta resep acuan, yang nantinya akan disubstitusikan dengan bahan pangan tradisional yaitu tepung ikan teri nasi. Percobaan pertama membuat satu resep acuan, dapat dilihat pada Table 1 .

Table 1 Recipe for semprong cakes

\begin{tabular}{lr}
\hline \multicolumn{1}{c}{ Item } & Composition \\
\hline Rice flour $(\mathrm{g})$ & 225 \\
Sago flour $(\mathrm{g})$ & 40 \\
Egg & 3 \\
Sugar $(\mathrm{g})$ & 150 \\
Margarine $(\mathrm{g})$ & 40 \\
Coconut milk (mL) & 200 \\
Sesame (g) & 40 \\
\hline Source: Wati (2013) &
\end{tabular}

Berdasarkan resep acuan dapat dihasilkan produk yang renyah, berwarna putih kecokelatan, aroma khas semprong dan mempunyai rasa yang manis. Selanjutnya membuat produk sesuai resep acuan dengan substitusi tepung ikan teri nasi sebesar 5\%, 10\% dan 15\%. Hasil penelitian ini sejalan dengan penelitian Yulianti (2016) yang menunjukkan formula egg roll dengan penambahan tepung ikan teri sebesar 5,5\%, 6,5\%, dan 7,5\%.

\section{Design}

Tahap design dilakukan percobaan pada resep acuan yang terpilih dengan ditambahkan tepung ikan teri nasi pada formula $5 \%, 10 \%$, dan $15 \%$. Resep acuan dan ketiga resep pengembangan dapat dilihat pada Table 2 .

Formula produk diuji coba kepada dosen ahli gizi dan pangan sebanyak dua orang, kemudian dipilih yang paling baik. Formulasi yang terpilih yaitu substitusi $15 \%$ dengan berat tepung beras $190 \mathrm{~g}$ dan tepung ikan teri nasi $35 \mathrm{~g}$. Teksturnya renyah dan rasanya enak dengan kombinasi asin, gurih dan manis. Hasil penelitian Nopriani (2021) mengatakan bahwa substitusi tepung sagu dengan tepung ikan teri memberikan pengaruh nyata terhadap semua karakteristik organoleptik dan kandungan proksimat kukis bagea. Produk yang terpilih adalah substitusi $15 \%$ dengan berat tepung sagu $85 \mathrm{~g}$ dan tepung ikan teri $15 \mathrm{~g}$.

\section{Development}

Tahap ini adalah validasi oleh dua dosen ahli gizi dan pangan sebanyak satu kali dan merancang kemasan beserta harga jual. Hasil validasi untuk kue semprong teri medan pada formula $15 \%$ tepung teri medan. Komentar dari dosen ahli gizi dan pangan memperbaiki bentuk gulungan dari kue semprong, agar terlihat lebih rapi dan menarik. Hasil penilaian untuk kue semprong teri medan dengan substitusi $15 \%$ ini menghasilkan produk pengembangan yang lebih disukai oleh dosen ahli gizi dan pangan.

Pengemasan adalah suatu kegiatan merancang dan memproduksi bungkus 
Table 2 Recipe for research and development of semprong cake

\begin{tabular}{lrrrr}
\hline \multirow{2}{*}{ Item } & \multirow{4}{*}{ Base recipe } & \multicolumn{3}{c}{ Anchovy powder (\%) } \\
\cline { 3 - 5 } & 225 & 213 & 202 & 190 \\
\hline Rice flour (g) & 40 & 40 & 40 & 40 \\
Sago flour (g) & - & 12 & 23 & 35 \\
Anchovy powder (g) & 175 & 175 & 175 & 175 \\
Egg (g) & 150 & 150 & 150 & 150 \\
Sugar (g) & 40 & 40 & 40 & 40 \\
Margarine (g) & 200 & 200 & 200 & 200 \\
Coconut milk (mL) & 40 & 40 & 40 & 40 \\
Sesame (g) & & & &
\end{tabular}

suatu produk yang meliputi desain bungkus dan pembuatan bungkus produk tersebut (Susetyarsi 2012). Label juga tidak dapat dipisahkan dengan kemasan, karena label bagian dari kemasan secara keseluruhan dan harus di pertimbangkan pada tahap awal dalam proses desain kemasan. Dalam penelitian ini menggunakan dua ukuran kemasan, yaitu $100 \mathrm{~g}$ dan $500 \mathrm{~g}$. Bentuk kemasan dapat dilihat pada Figure 3.

\section{Disseminate}

Setelah melakukan uji validasi, langkah selanjutnya adalah uji kesukaan atau organoleptik dengan menggunakan score sheet dan diolah secara statistik. Setelah dilakukan uji organoleptik, maka dilakukan uji proksimat dan kalsium di laboratorium kimia.

\section{Uji Organoleptik}

Beberapa faktor yang dapat memengaruhi hasil organoleptik dapat berasal dari faktor internal maupun eksternal. Uji organoleptik pada penelitian ini dilakukan dengan menguji dua sampel yaitu pada produk acuan kue semprong dan produk pengembangan kue semprong teri medan. Adapun hasil penilaian dari uji organoleptik pada kedua sampel dapat dilihat pada Table 3 .

Berdasarkan hasil uji organoleptik menunjukkan bahwa produk pengembangan disukai panelis jika dilihat dari parameter warna, aroma, rasa, tekstur dan keseluruhan. Terdapat perbedaan antara produk acuan dan pengembangan.

\section{Warna}

Hasil uji-t berpasangan pada parameter warna menunjukkan ada perbedaan warna pada produk acuan dan produk pengembangan. Hal ini membuktikan bahwa kue semprong produk pengembangan dengan substitusi tepung ikan teri 15\% lebih disukai oleh panelis. Hasil penelitian Lianitya (2012) menyatakan bahwa semakin banyak tepung ikan teri nasi yang ditambahkan, maka warna biskuit akan semakin gelap karena warna cokelat pada tepung ikan teri nasi akan lebih dominan. Akibatnya, warna biskuit akan semakin cokelat (gelap) yang menyebabkan penurunan rata-rata kesukaan panelis

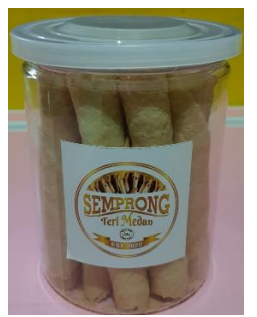

(A)

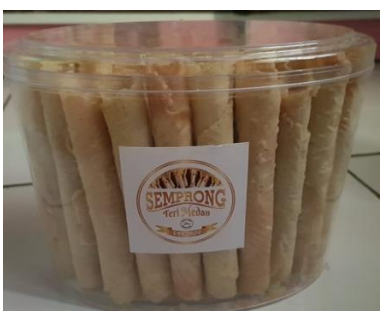

(B)

Figure 3 Packaging of the anchovy semprong cake; (A) $100 \mathrm{~g}$; (B) $500 \mathrm{~g}$ 
terhadap warna biskuit. Hal ini juga disebabkan oleh denaturasi protein yang disebabkan oleh proses Maillard yang terjadi sehingga terjadinya browning yang menyebabkan produk menjadi warna kecokelatan (Hidayat et al. 2013).

\section{Aroma}

Hasil analisis tingkat kesukaan terhadap penambahan tepung ikan teri nasi pada produk kue semprong menghasilkan aroma yang berbeda tapi lebih disenangi oleh panelis karena ada penambahan bubuk vanili dan biji wijen yang membuat aroma kue semprong teri medan tidak begitu amis. Hasil penelitian Ramadhan (2019) menyatakan uji daya terima kukis ikan teri yang paling disukai dengan substitusi tepung ikan teri sebanyak $20 \%$. Semakin banyak tepung ikan teri yang ditambahkan pada formula kukis, maka rata-rata kesukaan panelis terhadap aroma akan semakin kecil. Panelis belum terbiasa dengan aroma ikan teri pada kukis yang lebih dominan.

\section{Rasa}

Tingkat kesukaan panelis terhadap rasa kue semprong dengan substitusi tepung ikan teri nasi menghasilkan rasa gurih, manis, dan sedikit asin. Hasil uji-t berpasangan menunjukkan bahwa terdapat perbedaan rasa pada produk acuan dan pengembangan. Penelitian ini sesuai dengan Asyik (2018), yang menyatakan bahwa rasa biskuit yang disukai panelis diduga karena tepung ikan teri yang ditambahkan pada produk hanya sebesar $10 \%$, dengan rasa yang sedikit asin produk dikategorikan agak suka.

\section{Tekstur}

Hasil uji-t berpasangan pada parameter tekstur menunjukkan terdapat perbedaan tekstur antara produk acuan dan pengembangan. Tekstur kue semprong teri medan lebih disukai daripada produk acuan. Pada penelitian ini tekstur kue semprong juga tidak terlepas dari peran tepung sagu. Dibandingkan dengan amilosa, tepung sagu memiliki kandungan amilopektin yang lebih tinggi. Menurut Wirakartakusumah (1986), tekstur makanan sangat tergantung pada kadar air, kadar lemak, total karbohidrat, dan protein. Tekstur juga terpengaruh dengan amilopektin, semakin tinggi kandungan amilopektin pada bahan pangan maka semakin tinggi pula daya kembangnya. Tepung sagu mengandung sekitar 27\% amilosa dan $73 \%$ amilopektin. Rasio amilosa akan memengaruhi sifat pati itu sendiri. Jika kandungan amilosa tinggi, pati akan menjadi kering, tidak terlalu lengket dan cenderung menyerap lebih banyak air (hidroskopis).

\section{Kandungan Gizi}

Hasil uji proksimat dan kalsium pada produk pengembangan yaitu kue semprong teri medan dapat dilihat pada Table 4 dengan membandingkan produk acuan yaitu kue semprong dari penelitian sebelumnya. Bahan yang digunakan yaitu tepung beras, gula, garam, dan telur.

Hasil uji kandungan gizi menunjukkan bahwa kandungan protein kue semprong teri medan sebesar $10,77 \mathrm{~g}$, lebih tinggi dari kue semprong original sebesar 6,24 g. Kandungan lemak kue semprong teri medan sebesar 26,49 g. Kandungan karbohidrat kue semprong teri medan sebesar 57,04 g, lebih

Table 3 Organoleptic test of the semprong cake with and without anchovy powder

\begin{tabular}{lll}
\hline Parameter & Original & Enriched \\
\hline Color & $4.13 \pm 0.34^{\mathrm{b}}$ & $4.89 \pm 0.31^{\mathrm{a}}$ \\
Aroma & $4.03 \pm 0.17^{\mathrm{b}}$ & $4.97 \pm 0.17^{\mathrm{a}}$ \\
Taste & $4.06 \pm 0.24^{\mathrm{a}}$ & $4.89 \pm 0.31^{\mathrm{b}}$ \\
Texture & $4.19 \pm 0,39^{\mathrm{b}}$ & $4.99 \pm 0.10^{\mathrm{a}}$ \\
Overall & $4.01 \pm 0.10^{\mathrm{b}}$ & $4.96 \pm 0.20^{\mathrm{a}}$ \\
\hline Note: different letter on the same rows shows a significant \\
\multicolumn{2}{c}{ differences $(p<0.05)$}
\end{tabular}


Table 4 Proximate and calcium test results of the semprong cake with and without anchovy powder

\begin{tabular}{lrr}
\hline \multicolumn{1}{c}{ Parameter } & Original $^{*}$ & Enriched \\
\hline Protein $(\mathrm{g})$ & 6.24 & 10.77 \\
Fat $(\mathrm{g})$ & - & 26.49 \\
Carbohydrate $(\mathrm{g})$ & 63.80 & 57.04 \\
Energy (kcal) & 341.50 & 486.65 \\
Calcium (mg/100 g) & 8.60 & 820.63 \\
\hline Source: Erika Dwi (2016) & &
\end{tabular}

rendah dari kue semprong original sebesar 63,80 g. Kandungan energi kue semprong teri medan sebesar $486 \mathrm{kkal}$, lebih tinggi dari kue semprong original sebesar $341,5 \mathrm{kkal}$. Hasil uji kalsium menunjukkan bahwa kalsium kue semprong teri medan sebesar $820,63 \mathrm{mg}$, lebih tinggi dari kue semprong original sebesar 8,6 mg.

Menurut Peraturan Kepala BPOM Nomor 13 Tahun 2016 tentang Pengawasan Klaim pada Label dan Iklan Pangan Olahan, kandungan kalsium pada kue semprong teri medan yang mencapai $820,63 \mathrm{mg} / 100 \mathrm{~g}$ sampel dapat diklaim sebagai sumber kalsium. Putra et al. (2015) mengatakan bahwa tulang ikan teri mengandung mineral kalsium yang dapat memengaruhi nilai kalsium dari produk yang dibuat dengan tambahan tepung ikan teri. Kadar kalsium akan meningkat jika semakin banyak penambahan tepung ikan teri. Hal ini karena tepung ikan teri mengandung kalsium yang cukup tinggi yaitu $1.684,15 \mathrm{mg}$.

\section{Informasi Nilai Gizi}

Setelah uji laboratorium, langkah selanjutnya adalah menghasilkan informasi nilai gizi dan membuat label pada kemasan produk. Informasi nilai gizi dihitung berdasarkan angka kecukupan gizi (AKG) anak usia 10-12. Hasil informasi gizi dapat dilihat pada Figure 5.

Informasi tentang nilai gizi menunjukkan bahwa zat gizi di dalamnya membantu memenuhi kebutuhan sehari-hari. Kalsium sangat membantu untuk pembentukan dan pemeliharaan kepadatan tulang dan gigi. Persyaratan setiap produk yang mengandung kalsium lebih dari $400 \mathrm{mg}$ harus disertai dengan pernyataan bahwa asupan lebih dari 2000 mg per hari tidak akan meningkatkan manfaat dalam menjaga kepadatan tulang (BPOM 2016). Kontribusi produk olahan berbahan dasar tepung ikan teri nasi terhadap protein, lemak, karbohidrat dan kalsium dapat dilihat pada Table 5.

Kue semprong teri medan dengan memanfaatkan ikan teri nasi menjadi tepung dengan formula terpilih menyumbang $2,65 \mathrm{~g}$ per sajian, sehingga dapat menyumbang $4 \%$ AKG untuk anak usia 10-12 tahun. Setiap porsi dapat menyediakan hingga $1,08 \mathrm{~g}$ atau $1 \mathrm{~g}$ protein, sehingga dapat menyumbang

\begin{tabular}{|c|c|c|}
\hline \multicolumn{3}{|c|}{ NUTRITION FACTS } \\
\hline Serving Size & $10 \mathrm{~g}$ & Weight $100 \mathrm{~g}$ \\
\hline \multicolumn{3}{|l|}{ Amount Per Serving } \\
\hline Calories & $51 \mathrm{kcal}$ & \\
\hline \multirow[t]{2}{*}{ Calories from Fat } & $24 \mathrm{kcal}$ & \\
\hline & & \% Daily Value \\
\hline Total Fat & $3 g$ & 4 \\
\hline Protein & $1 \mathrm{~g}$ & 2 \\
\hline Total carbohydrate & $6 \mathrm{~g}$ & 2 \\
\hline Calcium & $82 \mathrm{mg}$ & 8 \\
\hline \multicolumn{3}{|c|}{$\begin{array}{l}{ }^{*} \text { Percent daily values are based on a } 1850 \mathrm{kcal} \text {. You daily } \\
\text { values may be higher or lower depending on your calorie } \\
\text { needs. }\end{array}$} \\
\hline
\end{tabular}

Figure 5 Information on the nutritional value of the anchovy semprong cake 
Table 5 Contribution of nutrients from anchovy semprong cake

\begin{tabular}{lrrr}
\hline Nutrient content & $\begin{array}{c}\text { Nutrient per } \\
\text { serving }\end{array}$ & $\begin{array}{c}\text { Recommended dietary } \\
\text { allowances (RDA) for } \\
\text { children 10-12 years }\end{array}$ & $\begin{array}{c}\text { Contribution } \\
\text { to RDA (\%) }\end{array}$ \\
\hline Protein (g) & 1.08 & 49 & 2.20 \\
Fat (g) & 2.65 & 72 & 3.68 \\
Carbohydrate (g) & 5.70 & 254 & 2.25 \\
Energy (kcal) & 50.96 & 1,850 & 2.75 \\
Calcium (mg/100 g) & 82.06 & 1,000 & 8.21 \\
\hline
\end{tabular}

2\% AKG untuk kategori anak 10-12 tahun. Setiap porsi menyediakan $5,70 \mathrm{~g}$ atau $6 \mathrm{~g}$ karbohidrat, sehingga dapat menyumbang $2 \%$ dari AKG untuk anak usia 10-12. Setiap porsi menyediakan $83,06 \mathrm{mg}$ atau $82 \mathrm{mg}$ kalsium, sehingga dapat menyumbang $8 \%$ dari AKG untuk anak usia 10-12 tahun. Rahmawati et al. (2013) mengatakan semakin tinggi substitusi tepung ikan teri pada kukis akan meningkatkan kadar kalsium. Kukis dengan substitusi tepung tempe sebesar 15\% dan tepung ikan teri sebesar 5\% memiliki kadar kalsium yang lebih tinggi.

\section{KESIMPULAN}

Formula terbaik pembuatan kue semprong adalah dengan substitusi tepung ikan teri nasi sebesar $15 \%$. Hasil penelitian menunjukkan bahwa penambahan tepung ikan teri nasi terhadap kue semprong berpengaruh nyata terhadap warna, aroma, rasa, tekstur, protein, lemak, karbohidrat, energi, dan kalsium. Berdasarkan hasil penelitian diperoleh nilai rata-rata organoleptik produk acuan sebesar 4,0 dan produk pengembangan 4,9 atau sangat disukai. Informasi nilai gizi produk pengembangan kue semprong teri medan memenuhi kebutuhan harian dari AKG anak usia 10-12 tahun. Oleh karena itu, produk kue semprong teri medan dapat dikatakan sebagai camilan yang dapat dijadikan sebagai sumber kalsium untuk anak sekolah.

\section{DAFTAR PUSTAKA}

Amin MZ, Nugroho LPE, Nurjanah. 2018. Kajian implementasi GMP dan SSOP ikan teri nasi setengah kering di Kabupaten Tuban. Jurnal Pengolahan Hasil Perikanan Indonesia. 21(3): 406-413
Asyik, Ansharullah, Rusdin H. 2018. Formulasi Pembuatan Biskuit Berbasis Tepung Komposit Sagu dan Tepung Ikan Teri. Biowallacea. 5(1): 696-787

[BPOM RI]. Badan Pengawas Obat dan Makanan Republik Indonesia. 2016. Acuan Label Gizi. Jakarta (ID): Badan Pengawas Obat dan Makanan.

[BPOM RI]. Badan Pengawas Obat dan Makanan Republik Indonesia. 2016. Pengawasan Klaim pada Label dan Iklan Pangan Olahan. Jakarta (ID): Badan Pengawas Obat dan Makanan.

Faroj MN. 2019. Pengaruh substitusi tepung ikan teri (Stolephorus commersonii) dan tepung kacang merah (Vigna angularis) terhadap daya terima dan kandungan protein pie mini. Media Gizi Indonesia. 14(1): 56-65.

Hidayat T, Nurjanah, Suptijah P. 2013. Karakterisasi tepung buah lindur (Bruguiera gymnorrhiza) sebagai beras analog dengan penambahan sagu dan kitosan. Jurnal Pengolahan Hasil Perikanan Indonesia. 16(3): 268-277.

[KKP]. Kementerian Kelautan dan Perikanan. 2019. Data Angka Konsumsi Ikan (AKI) Nasional. Jakarta.

Lianitya CA, Kumalaningsih S, Mulyadi AF. 2012. Karakteristik organoleptik biskuit dengan penambahan tepung ikan teri nasi (Stolephorus). Jurnal Teknologi Pertanian. 12(3): 157-168.

Prisila E, Efrina E, Izzata R. 2020. Uji data terima terhadap modifikasi kue semprong dengan menambahkan ekstra kopi instan. Prosiding SNP2M (Seminar Nasional Penelitian dan Pengabdian Masyarakat) UNIM. Universitas Negeri Jakarta. 1(2): 
16-20.

Putra M, Nopianti R, Herpandi. 2015. Fortifikasi tepung tulang ikan gabus pada krupuk sebagai sumber kalsium. Jurnal Teknologi Hasil Perikanan. 4(2):128-139.

Rahman N, Naiu AS. 2021. Karakteristik kukis bagea tepung sagu (Metroxylon sp.) yang disubstitusi tepung ikan teri (Stolephorus indicus). Jambura Fish Processing Journal. 3(1): 16-26

Rahmawati H, Rustanti N. 2013. Pengaruh substitusi tepung tempe dan ikan teri nasi (Stolephorus sp.) terhadap kandungan protein, kalsium dan organoleptik cookies. Journal of Nutrition College. 2(3): 382-390.

Rahmi Y, Widya N, Anugerah PN, Tanuwijaya LK. 2018. Tepung ikan teri nasi (Stolephorus commersini Lac.) sebagai sumber kalsium dan protein pada corn flakes alternatif sarapan anak usia sekolah. Jurnal Gizi-Dietetik. 10(1): 7-13.

Ramadhan, Nuryanto, Wijayanti. 2019. Kandungan gizi berbasis tepung ikan teri (Stolephorus sp) sebagai PMT-P untuk balita gizi kurang. Journal of Nutrition College. 8(4):264-273

Setiyawati, Amelia. 2020. Kajian Substitusi Tepung Ikan Teri Nasi Kering (Stolephorus commersonii) Terhadap Pembuatan Roti Burger Dengan Pewarna Alami Ekstrak Bunga Telang (Clitoria ternatea L.) Sebagai Snack Tinggi Kalsium.
[Tugas Akhir]. Lampung (ID): Poltekkes Tanjungkarang.

Susetyarsi, Th. 2012. Kemasan produk ditinjau dari bahan kemasan, bentuk kemasan dan pelabelan pada kemasan pengaruhnya terhadap keputusan pembelian pada produk minuman mizone di Kota Semarang. Jurnal STIE Semarang. 4(3): 19-28.

Sudewi M. 2018. Perbandingan kadar kalsium dalam teri nasi kering dan teri nasi basah dengan metode spektrofotometri serapan atom. Jurnal Analisis Farmasi. 3(3): 223230.

Sulistyowati E, Wijaningsih W, Mintarsih SN. 2015. Pengaruh substitusi tepung kedelai dan tepung ikan teri terhadap kadar protein dan kalsium crackers. Jurnal Riset Kesehatan. 4(3): 813-818.

Wirakartakusumah. 1986. Isolation Characterization of Sago Strach and Its Utilization for Production of Liquid Sugar. Jakarta (ID): The Development of The Sago Palm and It's Product Report of The FAO/ BPP Technology Consultation.

Wati dan Aryuni D. 2013. Aneka Resep kue Dan Roti. Med Press Digital.

Yulianti, Efa F. 2016. Pengaruh Penambahan Tepung Ikan Teri (Stolephorus commersini) Pada Pembuatan Egg Roll Terhadap Daya Terima Konsumen. [skripsi]. Jakarta (ID): Universitas Negeri Jakarta. 